\title{
TINJAUAN YURIDIS TERHADAP EFEKTIVITAS PELAKSANAAN FUNGSI BHAYANGKARA PEMBINA KEAMANAN DAN KETERTIBAN MASYARATAKAT (BHABINKAMTIBMAS) DALAM WILAYAH HUKUM KEPOLISIAN DAERAH KEPULAUAN RIAU
}

\author{
Chintya Cen* \\ Olsera Indonesia Pratama
}

\begin{abstract}
Bhayangkara Community Security and Order Development (Bhabinkamtibmas) is the caretaker of the community police in the village / district. Bhabinkamtibmas has the task of carrying out a preventive function by partnering directly with the community. The purpose of this study is to determine the effectiveness of the implementation of the Bhabinkamtibmas function in the jurisdiction of the Riau Islands Regional Police as the Bhabinkamtibmas function has been regulated by Indonesian laws and regulations, namely the Regulation of the Head of the National Police of the Republic of Indonesia Number 3 of 2015 concerning Community Police, and the Decree of the Chief of Police Number: KEP / 773NII / 2016. This research was conducted using empirical legal research methods by using primary data obtained from interviews, random sampling of activities of the Riau Islands Regional Police Bhabinkamtibmas and activities of Bhabinkamtibmas members of each Polres within the jurisdiction of the Riau Islands Regional Police. The results of this study are that the implementation of Bhabinkamtibmas functions in the jurisdiction of the Riau Islands Regional Police has been carried out in accordance with the applicable laws and regulations. However, the implementation of the Bhabinkamtibmas function of the Riau Islands Regional Police has not been fully effective. The ineffective implementation of the Bhabinkamtibmas function is due to the unavailability of laws and regulations that specifically regulate the Bhabinkamtibmas function, the limited number of members of the Riau Islands Regional Police Bhabinkamtibmas, and limited facilities for the Riau Islands Regional Police.

Keywords : Effectiveness, Community Security and Order, Riau Islands Regional Police
\end{abstract}

\begin{abstract}
Abstrak
Bhayangkara Pembina Keamanan dan Ketertiban Masyarakat (Bhabinkamtibmas) merupakan pengemban polisi masyarakat di desa/kelurahan. Bhabinkamtibmas memiliki tugas mengemban fungsi preventif dengan cara bermitra secara langsung dengan masyarakat. Tujuan penelitian ini adalah mengetahui efektivitas pelaksanaan fungsi Bhabinkamtibmas dalam wilayah hukum Kepolisian Daerah Kepulauan Riau sebagaimana fungsi Bhabinkamtibmas telah diatur didalam peraturan perundang-undangan di Indonesia, yaitu Peraturan Kepala Kepolisian
\end{abstract}

* Alamat Korespondensi : chintya.uib160162@gmail.com 
Negara Republik Indonesia Nomor 3 Tahun 2015 tentang Pemolisian Masyarakat, dan Keputusan Kapolri Nomor: KEP/773NII/2016. Penelitian ini dilakukan dengan menggunakan metode penelitian hukum empiris dengan menggunakan data primer yang diperoleh dari hasil wawancara, pengambilan sampel data secara acak kegiatan Bhabinkamtibmas Kepolisian Daerah Kepulauan Riau dan kegiatan anggota Bhabinkamtibmas setiap Polres dalam wilayah hukum Kepolisian Daerah Kepulauan Riau. Adapun hasil penelitian ini ialah pelaksanaan fungsi Bhabinkamtibmas dalam wilayah hukum Kepolisian Daerah Kepulauan Riau telah dilaksanakan sejalan dengan peraturan perundangan-undangan yang berlaku. Namun pelaksanaan fungsi Bhabinkamtibmas Kepolisian Daerah Kepulauan Riau belum sepenuhnya efektif. Ketidakefektifan pelaksanaan fungsi Bhabinkamtibmas disebabkan tidak tersedianya peraturan perundang-undangan yang secara spesifik mengatur fungsi Bhabinkamtibmas, keterbatasan jumlah anggota Bhabinkamtibmas Kepolisian Daerah Kepulauan Riau, keterbatasan sarana dan fasilitas bagi Bhabinkamtibmas Kepolisian Daerah Kepulauan Riau.

Kata Kunci : Efektivitas, Bhabinkamtibmas, Kepolisian Daerah Kepulauan Riau

\section{A. Latar Belakang Masalah}

Manusia merupakan makhluk sosial yang tidak dapat dipisahkan dari interaksi sosial di masyarakat. Interaksi merupakan hubungan atau hal saling memberikan aksi. Manusia berinteraksi baik antara individu dengan individu, individu dengan kelompok atau kelompok dengan kelompok. Perkembangan jaman memberikan dampak perubahan terhadap pola pikir, pola perilaku maupun pola interaksi dalam kehidupan sosial dimasyarakat. Perubahan pola pikir, pola perilaku serta pola interasksi yang terbentuk dimasyarakat sebagian meningkatkan suatu kemajuan namun dilain sisi justru membentuk timbulnya berbagai bentuk kejahatan. ${ }^{1}$

Indonesia merupakan negara hukum yang menjabarkan berbagai bentuk tindak kejahatan yang dapat dilakukan oleh manusia. Kejahatan itu sendiri diatur didalam Kitab Undang-Undang Hukum Pidana (KUHP) dan pelaksanaannya diatur pula dalam Kitab Undang-Undang Hukum Acara Pidana (KUHAP). Selain KUHP, kejahatan juga diatur dalam beberapa undang-undang lainnya. Perbuatan pidana selalu berkaitan dengan sifat dan bentuk pelanggaran yang dilarang dan bentuk pertanggungjawaban oleh pelaku berupa penjatuhan sanksi pidana kurungan penjara dan/atau denda sejumlah uang. ${ }^{2}$

Setiap anggota masyarakat berpeluang menciptakan berbagai jenis kejahatan yang dapat mengganggu keamanan, ketentraman dan ketertiban masyarakat sekitarnya. Disisi lain, setiap personel masyarakat megharapkan lingkungan masyarakat yang aman, tentram dan tertib agar dapat senantiasa

1 Ni Made Kristiani, "Kejahatan Kekerasa Seksual (Perkosaan) Ditinjau dari Perspektif Kriminologi”, Jurnal Magister Hukum Udayana, Vol.7, No. 3, Tahun 2014, hal. 372.

${ }^{2}$ Bambang Poernomo, Asas-Asas Hukum Pidana, Jakarta: Ghalia Indonesia, 1988, hal. 18. 
melakukan aktifitas sehari-hari. Dengan terciptanya lingkungan masyarakat yang aman, tentram dan tertib akan meningkatkan taraf kehidupan dan kesejahteraan masyarakat. Namun, apabila tidak dapat diciptakannya lingkungan masyarakat yang aman, tentram dan tertib maka akan mengganggu tatanan kehidupan masyarakat dan dapat berpengaruh pada pemenuhan taraf kehidupan. Demi terciptanya tatanan masyarakat yang aman, tentram dan tertib, maka pemerintah Indonesia membentuk Kepolisian Negara Republik Indonesia.

Kepolisian Negara Republik Indonesia atau yang lebih sering disebut Polri merupakan kepolisian nasional di Indonesia yang bertanggung jawab langsung dibawah Presiden. Polri mengembang tugas-tugas kepolisian di seluruh wilayah Indonesia. Dalam melaksanakan tugasnya, Polri wajib untuk memberikan perlindungan, pengayoman dan pelayanan kepada masyarakat demi menjaga keutuhan dan ketertiban masyarakat serta melakukan penegakan hukum yang berlaku. Tugas dan fungsi Polri sendiri telah diatur dalam Peraturan Pemerintah Republik Indonesia Nomor 2 Tahun 2003 Tentang Peraturan Disiplin Personel Kepolisian Negara Republik Indonesia.

Sejalan dengan program pemerintah terkait dengan paket kebijakan hukum jilid II, terdapat tiga fokus yaitu penataan regulasi, perluasan bantuan hukum dan jaminan rasa aman. Pada fokus jaminan rasa aman, maka pemerintah mengembangkan Pemolisian Masyarakat (Polmas) untuk membangun sistem peringatan dini terhadap tindak kejahatan. ${ }^{3}$ Konsep Polmas tersebut dibakukan pada 13 Oktober 2005 melalui Keputusan Kapolri No. Pol. Skep/737/X/2005 ${ }^{4}$ dimana Polmas tersebut merupakan kebijakan baru yang harus diterapkan oleh seluruh jajaran Polri. Dalam Peraturan Kapolri Nomor 3 Tahun 2015, disebutkan bahwa Polmas merupakan sebuah kegiatan untuk mengajak masyarakat melalui kemitraan personel Polri dan masyarakat dalam mendeteksi dan mengidentifikasi permasalahan keamanan dan ketertiban masyarakat (Kamtibmas) dilingkungan serta menemukan pemecahan masalahnya. ${ }^{5}$

Bhayangkara Pembina Keamanan dan Ketertiban Masyarakat atau yang biasa disebut Bhabinkamtibmas, merupakan pengemban polisi masyarakat di desa/kelurahan. Bhabinkamtibmas memiliki tugas untuk mengemban fungsi preventif dengan cara bermitra dengan masyarakat secara langsung. Bhabinkamtibmas memiliki wewenang untuk menyelesaikan masalah, mengambil langkah-langkah yang diperlukan sebagai bentuk tindak lanjut dalam pemeliharaan keamanan lingkungan, mendatangi tempat kejadian perkara serta mengawasi aliran kepercayaan masyarakat yang dapat menimbulkan perpecahan atau mengancam persatuan dan kesatuan bangsa.

\footnotetext{
3 Admin, "Ini 3 Agenda Paket Reformasi Jilid II" https://www.hukumonline.com/berita/baca/lt587e0fdb06ea8/ini-3-agenda-paket-reformasi-hukumjilid-ii/, diunggah pada 17 Januari 2017.

${ }^{4}$ Indonesia, Keputusan Kapolri No. Pol. Skep/737/X/2005

${ }^{5}$ Indonesia, Peraturan Kapolri Nomor 3 Tahun 2015
} 
Berdasarkan Laporan Analisa dan Evaluasi Data Kriminalitas Tindak Pidana Umum Pada Ditreskrimum dan Satreskrimum Jajaran Kepolisian Daerah Kepulauan Riau Bulan September 2018 terkait dengan pertahanan dan keamanan didapati hasil secara umum situasi keamanan wilayah hukum Kepolisian Daerah Kepulauan Riau masih kondusif namun disertai dengan beberapa kasus kriminalitas di Kota Batam seperti curanmor, curas, curat, perdagangan narkoba, human trafficking, hingga aksi teroris. Berdasarkan hasil analisa dan evaluasi laporan, gangguan kamtibmas (keamanan dan ketertiban masyarakat) bulan agustus 2018 mengalami kenaikan sebanyak 56 kasus atau $8 \%$ dibandingkan bulan sebelumnya dan tingkat kemampuan penyelesaian perkara mengalami kenaikan sebesar 12 kasus atau $6 \%$ dibandingkan dengan bulan sebelumnya ${ }^{6}$.

Oleh karena itu, Penulis tertarik untuk melakukan penelitian dengan judul Tinjauan Yuridis Terhadap Efektivitas Pelaksanaan Fungsi Oleh Bhayangkara Pembina Keamanan dan Ketertiban Masyarakat (Bhabinkamtibmas) dalam Wilayah Hukum Kepolisian Daerah Kepulauan Riau.

\section{B. Rumusan Masalah}

Adapun rumusan masalah dari penelitian ini, sebagai berikut:

1. Bagaimanakah pelaksanaan fungsi Bhabinkamtibmas dalam wilayah hukum Kepolisian Daerah Kepulauan Riau?

2. Bagaimana efektivitas pelaksanaan fungsi Bhabinkamtibmas dalam wilayah hukum Kepolisian Daerah Kepulauan Riau?

\section{Metode Penelitian}

Penelitian yang ditujukan untuk menganalisis permasalahan yang dirumuskan diatas, dilakukan dengan metode pendekatan Yuridis Empiris. Penelitian hukum normatif atau penelitian perpustakaan ini merupakan penelitian yang mengkaji studi dokumen, yakni menggunakan berbagai data sekunder seperti seperti peraturan perundang-udangan, keputusan pengadilan, teori hukum, dan dapat berupa pendapat para sarjana.Penulis akan melakukan penelitian dengan mengambil beberapa ide dari Peter Mahmud namun sebagian besar akan mengikuti pola umum yang banyak dilakukan di sekolah hukum di Indonesia dengan tetap mengacu pada pola penelitian dalam studi politik hukum.

Kegiatan yang dilakukan dalam pengumpulan data dalam penelitian ini yaitu dengan cara mengumpulkan (dokumentasi) data sekunder berupa pendapat para ahli, tulisan-tulisan dalam buku ilmiah, dokumen, arsip, literatur, makalah, dan bahan kepustakaan lainnya yang berhubungan erat dengan

\footnotetext{
${ }^{6}$ Hernowo Yuliantor, "Laporan Analisa dan Evaluasi Data Kriminalitas Tindak Pidana Umum Pada Ditreskrimum dan Satreskrimum Jajaran Polda Kepri Bulan Oktober 2018". http://kepri.polri.go.id/pid/wp-content/uploads/2018/11/LAPBUL-ANEV-DATAKRIMINALITAS-BULAN-OKT-2018.pdf, diunggah pada 19 November 2018.
} 
masalah yang penulis teliti.Peneliti melakukan studi dokumen terhadap bukubuku dan literatur-literatur yang berhubungan dengan penelitian ini untuk memperoleh landasan teoritis yang dapat digunakan untuk menganalisis fungsi Bhabinkamtibmas dalam wilayah hukum Kepolisian Daerah Kepulauan Riau.

\section{Hasil Penelitian dan Pembahasan}

\section{1) Hasil Penelitian}

Menelaah Keputusan Kepala Kepolisian Negara Republik Indonesia (Nomor:Kep/773/VII/2016) tentang Buku Pintar Bhabinkamtibas, setiap personel Bhabinkamtibmas memegang peranan penting didalam masyarakat. Tugas pokok Bhabinkamtibmas adalah membina masyarakat agar dapat terciptanya keadaan yang memberikan keuntungan atau manfaat dalam pelaksanaan tugas Polri di desa/kelurahan. Tugas-tugas yang dilaksanaan memiliki kaitan yang erat dengan fungsi Bhabinkamtibmas.

Tugas lainnya yang harus diemban oleh seorang Bhabinkamtibmas meliputi melakukan pembinaan kepada warga sehingga diharapkan dapat meningkatkan peran atau partisipasi masyarakat, mencitpakan kesadaran dan ketaatan masyarakat terhadap hukum peraturan perundang-undangan yang berlaku. Personel Bhabinkamtibmas juga perlu menjalin hubungan yang baik dengan tokoh-tokoh desa, tokoh masyarakat, tokoh agama, tokoh pemuda, tokoh adat dan sesepuhnya disuatu desa/kelurahan agar dapat melaksanakan kegiatan kerjasama serta membangun kepercayaan terhadap masyarakat. Setiap personel Bhabinkamtibmas dibekali dengan wawasan dan kemampuan mendeteksi dini terhadap isu atau permasalahan yang berkembang di masyarakat sehingga Bhabinkamtibmas dapat melakukan upaya preventif atau solusi yang sifatnya mengantisipasi potensi ganggungan dan ambang gangguan yang terjadi di masyarakat agar selanjutnya tidak berkembang menjadi gangguan nyata kamtibmas.

Bhabinkamtibmas terus melakukan inovasi-inovasi terbaru. Inovasi yang baru diluncurkan adalah sebuah aplikasi android berbasis online untuk personel Binmas. Aplikasi tersebut dinamakan Go-Binmas. Aplikasi Go-Binmas dapat mengirimkan dan menyimpan laporan kegiatan per-Bhabinkamtibmas, laporan kegiatan per-Polsek, laporan kegiatan per-Polres, menampilkan ranking dari personel Binmas, berita, rencana kegiatan, grafik per kegiatan dan grafik 20 besar.

Aplikasi Go-Binmas diharapkan dapat mempermudah sistem pelaporan kegiatan. Proses pelaporannya dapat dilakukan secara real time baik dalam keadaan ada maupun tanpa adanya jaringan internet. Jika keadaan internet sedang tidak stabil atau tidak ada jaringan internet, maka sistem akan secara otomatis melakukan proses pengiriman laporan ke server setelah terlacak jaringan internet. Laporan melalui aplikasi Go-Binmas dapat disertai dengan foto yang mana foto-foto tersebut diambil secara real time atau diambil dari galeri android namun dengan pembatasan waktu dari tanggal laporannya. 
Laporan yang masuk akan secara otomatis terhimpun dan sistem akan melakukan pemberian ranking atas Bhabinkamtibmas yang aktif.

Personel Bhabinkamtibmas diberikan beberapa fasilitas, sarana dan prasarana dari Mabes Polri untuk menjalankan tugasnya. Fasilitas tersebut berupa kendaraan motor (Ranmor R2 Patroli berupa Honda Verza 150cc lengkap dengan kelengkapan pendukungnya), speedboat air, dan handphone BOS (Binmas Online System).

Ditreskrimum bertugas untuk menyelenggarakan dan membina fungsi Reskrimum yang meliputi kegiatan-kegiatan penyelidikan dan penyidikan tindak pidana umum. Laporan analisa dan evaluasi ini menunjukan angka kriminalitas tindak pidana umum yang dilaporkan dan diselesaikan oleh Kepolisian Daerah Kepulauan Riau.

Adapun tindak pidana yang sering terjadi adalah kesengajaan masyarakat untuk menimbulkan kebakaran, pencemaran nama baik, kelalaian yang menimbulkan kebakaran, perkosaan, pengeroyokan, palsu surat (penggelapan surat, keterangan palsu, penggelapan tanda tangan), perjudian, TKI Ilegal, penganiayaan ringan, penganiayaan berat, pencurian biasa, pencurian berat, curanmor, pencurian ringan, pencurian dengan kekerasan, peras dan ancam, penggelapan, penipuan, tipu gelap, pengrusakan barang, penjambretan, orang hilang, kekerasan dalam rumah tangga, penemuan mayat, perbuatan cabul, terkait perlindungan anak, tentang tanah (terkait perkarangan rumah atau halaman rumah), pengrusakan dan pencurian, bunuh diri, meninggal dunia, kecelakaan kerja dan penadahan.

\section{2) Pembahasan}

Berdasarkan data-data yang Penulis peroleh diatas, Penulis melakukan pengolahan dan penganalisaan data sesuai dengan judul yang diteliti terkait efektivitas pelaksanaan fungsi Bhabinkamtibmas dalam wilayah hukum Kepolisian Daerah Kepulauan Riau.

\section{Pelaksanaan Fungsi Bhabinkamtibmas Kepolisian Daerah Kepulauan Riau}

Mengkaji Keputusan Kapolri Nomor : KEP/773NII/2016 yang diterbitkan tanggal 29 Juli 2019 tentang Buku Pintar Bhabinkamtibmas, bahwa setiap personel Bhabinkamtibmas memiliki fungsi untuk :

a. membimbing dan menyuluh di bidang hukum dan kamtibmas;

b. melayani masyarakat tentang hal-hal yang berkaitan dengan permasalahan kamtibmas;

c. membina ketertiban masyarakat terhadap norma-norma yang berlaku;

d. memediasi dan memfasilitasi upaya pemecahan masalah yang terjadi di masyarakat;

e. mendinamisir aktivitas masyarakat yang bersifat positif;

f. mengkoordinasikan upaya pembinaan kamtibmas dengan perangkat desa/kelurahan, Babinsa dan pihak-pihak terkait lainnya. 
Berdasarkan laporan kegiatan harian yang dilaksanakan oleh Binmas Kepolisian Daerah Kepulauan Riau maupun personel Bhabinkamtibmas Kepolisian Daerah Kepulauan Riau, didapati hasil bahwa fungsi Bhabinkamtibmas telah terlaksana sesuai dengan Keputusan Kapolri Nomor : KEP/773NII/2016 dan Perkap Nomor 3 Tahun 2015 tentang Polmas. Adapun perincian fungsi Bhabinkamtibmas dan kegiatan yang dilaksanakan dirincikan sebagai berikut :

\section{a. Membimbing dan menyuluh di bidang hukum dan kamtibmas}

Pelaksanaan fungsi pertama dilaksanakan dalam 3 kegiatan utama yaitu kegiatan sambang, kegiatan himbuan dan kegiatan pembinaan. Penulis berfokus pada kegiatan yang dilaksanakan oleh personel Bhabinkamtibmas di masing-masing Polres dalam wilayah hukum Kepolisian Daerah Kepulauan Riau, dimana dalam 3 bulan terakhir (bulan oktober, bulan november dan bulan desember tahun 2019) personel Bhabinkamtibmas Kepolisian Daerah Kepulauan Riau telah melakukan himbauan sebanyak 783x kegiatan sambang, 369x kegiatan himbauan dan 619x kegiatan pembinaan.

Kegiatan sambang maupun himbauan dilaksanakan secara langsung door to door kepada setiap warga binaannya maupun secara massal dengan mengadakan kegiatan Basembang Bercerita di fasilitas umum wilayah setempat. Kegiatan-kegiatan ini dilaksanakan pada tanggal tertentu di setiap bulannya.

Penulis mengambil beberapa contoh himbauan dan pembinaan yang dilaksanakan. Secara garis besar himbauan yang diberikan terkait dengan himbauan kepada masyarakat untuk selalu menjaga keadaan lingkungan sekitar agar tetap aman, kondusif dan tertib. Masyarakat dihimbau untuk selalu mewaspadai setiap pendatang baru yang memasuki wilayah tempat tinggal mereka. Bilamana terjadi hal-hal yang dicemaskan atau tidak diinginkan, warga dapat sesegera mungkin menghubungi personel Bhabinkamtibmas setempat.

Pembinaan yang dilaksanakan seperti membina masyarakat untuk melaksanakan kembali sistem siskamling di setiap kampung, tujuannya untuk menjaga keadaan kamtibmas yang kondusif dan aman. Seiring dengan perkembang isu nasional. Ini berkaitan dengan himbauan yang diberikan kepada masyarakat agar masyarakat lebih bijak dalam menggunakan media sosial dan menyebarkan berita yang mereka dapati. Dalam hal ini personel Bhabinkamtibmas membina masyarakat untuk tidak turut menyebarkan berita bohong atau ujaran kebencian yang dapat menyebabkan perpecahan kebangsaan. Dalam menyampaikan materinya, personel Bhabinkamtibmas menerangkan bahwa menyebarkan berita bohong atau ujaran kebencian merupakan tindak pidana yang dapat berakibat pemberian saksi pidana kepada orang yang melakukannya. 
b. Melayani masyarakat tentang hal-hal yang berkaitan dengan permasalahan kamtibmas

Fungsi melayani masyarakat tentang hal-hal yang berkaitan dengan permasalahan kamtibmas adalah pengadaan PAM. PAM merupakan kegiatan menjaga pengamanan dan keamanan diwilayah binaan setiap personel Bhabinkamtibmas.

Berdasarkan laporan kegiatan yang dilaksanakan oleh personel Bhabinkamtibmas di setiap Polres dalam wilayah hukum Kepolisian Daerah Kepulauan Riau, pada 3 bulan terakhir yaitu bulan oktober, november dan desember tahun 2019 telah dilaksanakan PAM sebanyak 46x.

c. Membina ketertiban masyarakat terhadap norma-norma yang berlaku

Terkait dengan fungsi membina ketertiban masyarakat terhadap norma-norma yang berlaku, kegiatan yang sering dilaksanakan adalah himbauan dan pembinaan. Contohnya himbauan terkait radikalisme yang sedang menjadi isu nasional. Masyarakat dihimbau untuk lebih mewaspadai ajaran-ajaran radikalisme yang bertentangan dengan norma di masyarakat dan ajaran agama.

Bhabinkamtibmas menghimbau kepada masyarakat bahwa perkembangan ajaran radikalisme tidak mengenal orang perorangan maupun suatu kelompok tertentu. Selain bertentangan dengan moral, norma dan nilai-nilai keagamaan, radikalisme juga bertentangan dengan 4 pilar kebangsaan. Kegiatan himbauan seperti ini yang sering di berikan kepada masyarakat dalam fungsi menjaga norma-norma yang berlaku.

d. Memediasi dan memfasilitasi upaya pemecahan masalah yang terjadi di masyarakat

Bhabinkamtibmas memiliki fungsi untuk memediasi dan memfasilitasi pemecahan masalah yang terjadi di masyarakat. Kegiatan yang sering terjadi di masyarakat adalah perbedaan pendapat antar warga, saling tersinggung satu sama lain, bahkan permasalah rumah tangga seperti KDRT, perselisihan suami-istri, dan sebagainya.

Pelaksanaan fungsi tersebut dilakukan oleh personel Bhabinkamtibmas dengan pemecahan masalah, meredakan situasi yang sedang tidak kondusif, sebagai penengah konflik antar pihak. Hal ini terbukti telah dilaksanakan personel Bhabinkamtibmas dalam laporan kegiatan personel Bhabinkamtibmas per Polres dalam wilayah hukum Kepolisian Daerah Kepulauan Riau selama 3 bulan terakhir yaitu bulan oktober, november dan desember tahun 2019 sebanyak 16x pemecahan masalah. 


\section{e. Mendinamisir aktivitas masyarakat yang bersifat positif}

Bhabinkamtibmas memiliki memiliki peran sebagai promotor dalam mendinamisir aktivitas masyarakat yang bersifat positif. Untuk menjalankan fungsinya, Bhabinkamtibmas mengajak serta masyarakat melakukan beberapa kegiatan rutin seperti gotong royong dan bakti sosial.

Berdasarkan laporan kegiatan Bhabinkamtibmas dalam 3 bulan terakhir yaitu bulan September, oktober dan november tahun 2019 didapati bahwa personel Bhabinkamtibmas Polres pada wilayah hukum Kepolisian Daerah Kepulauan Riau telah melaksanakan total gotong royong sebanyak 51x dan bakti sosial sebanyak 44x.

Kegiatan gotong royong dan bakti sosial dilaksanakan pada waktu tertentu dan juga mengikuti isu/permasalahan yang terjadi saat itu. Contohnya beberapa waktu lalu terjadi bencana alam banjir di Kecamatan Nongsa, Bhabinkamtibmas turut membantu warga dalam membersihkan rumah dan barang-barang yang terkena dampak banjir.

Kegiatan bakti sosial juga dilaksanakan oleh Bhabinkamtibmas yang bekerja sama dengan instansi terkait lainnya. Contohnya saat Kepri dilanda kabut asap akibat kebakaran hutan beberapa waktu lalu, Bhabinkamtibmas Kepolisian Daerah Kepulauan Riau bersama jajaran Dokter Bhayangkara membagikan masker gratis dan pengobatan gratis untuk mencegah ISPA pada warga setempat.

f. Mengkoordinasikan upaya pembinaan kamtibmas dengan perangkat desa/kelurahan, Babinsa dan pihak-pihak terkait lainnya

Fungsi mengkoordinasikan upaya pembinaan kamtibmas dengan perangkat desa/kelurahan, Babinsa dan pihak-pihak terkait lainnya telah dilaksanakan Bhabinkamtibmas tiap Polres dalam wilayah hukum Kepolisian Daerah Kepulauan Riau. Kegiatan yang berhubungan dengan fungsi tersebut adalah kegiatan rapat koordinator, latihan kemampuan dasar Bhabinkamtibmas, musyawarah rencana pembangunan (musrembang), dan shalat bersama warga setempat.

Berdasarkan laporan kegiatan personel Bhabinkamtibmas tiap Polres dalam wilayah hukum Kepolisian Daerah Kepulauan Riau, pada 3 bulan terakhir yaitu bulan September, oktober dan november telah dilaksanakan rapat koordinator sebanyak 36x, musrembang sebanyak 13x, dan latihan kemampuan dasar Bhabinkamtibmas untuk seluruh Polres dalam wilayah hukum Kepolisian Daerah Kepulauan Riau. Salah satu tujuan dilaksanakannya kegiatan tersebut adalah untuk meningkatkan solidaritas dan sinergitas antara Polri dengan masyarakat. Berdasarkan laporan penelitian yang telah dilaksanakan, Penulis menilai bahwa pelaksanaan fungsi-fungsi Bhabinkamtibmas telah dijalankan sebagaimana yang telah diatur dalam Keputusan Kapolri, Perkap Polri dan peraturan perundang-undangan yang berlaku lainnya. 


\section{Efektivitas Pelaksanaan Fungsi Bhabinkamtibmas Kepolisian Daerah Kepulauan Riau}

Penulis mengaitkan pelaksanaan fungsi Bhabinkamtibmas Kepolisian Daerah Kepulauan Riau dengan teori efektivitas hukum yang dicetuskan oleh Soerjono Soekanto. Menurut Soerjono Soekanto suatu masalah hukum yang timbul tidak terbatas pada suatu kepatutan atau ketaatan terhadap hukum itu, tapi mencakup efek dari hukum terhadap suatu perilaku baik bersifat positif maupun negatif dan faktor penegak hukumnya. Menurut Soerjono Soekanto terdapat beberapa faktor yang dapat dijadikan suatu indikator efektivitas hukum, yaitu faktor hukumnya sendiri, faktor penegak hukum, faktor sarana dan fasilitias, faktor masyarakat dan faktor kebudayaan.

Pelaksanaan fungsi Bhabinkamtibmas dikaitkan dengan jumlah tindak pidana yang terjadi pada tahun 2018 dan 2019. Dengan kehadiran Bhabinkamtibmas, diharapkan dapat dilakukannya upaya preventif terhadap tindak pidana di wilayah Kepulauan Riau. Dengan rendahnya tindak pidana yang terjadi, maka tindakan represif akan semakin rendah. Represif merupakan suatu tindakan pengendalian sosial yang dilakukan setelah suatu tindak pidana telah terjadi.

Pada Juli-Desember 2018 telah dilaporkannya 1658 kasus tindak pidana dalam wilayah hukum Kepolisian Daerah Kepulauan Riau dan terdapat 1418 kasus yang dapat diselesaikan. Sedangkan pada Juli-Desember 2019 telah dilaporkannya 1713 kasus tindak pidana dalam wilayah hukum Kepolisian Daerah Kepulauan Riau dan terdapat 1065 kasus yang dapat diselesaikan. Tindak pidana yang terjadi pada tahun 2019 mengalami peningkatan sebanyak 55 kasus dibandingkan pada tahun 2018. Meningkatnya tindak pidana pada tahun 2019 menandakan bahwa fungsi Bhabinkamtibmas sebagai upaya preventif belum terlaksana secara efektif.

1) Faktor hukumnya sendiri

Menurut Soerjono Soekanto, hukum akan efektif jika dapat memiliki unsur keadilan, kepastian dan kemanfaatan. Keadilan merupakan salah satu tujuan hukum yang paling fundamental. Menurut Hans Kelsen, hukum yang dapat memberikan keadilan adalah tatanan hukum yang positif, yaitu suatu tatanan yang dapat bekerja secara sistematis. Dengan demikian, keadilan adalah keadilan yang sudah tertuang dalam peraturan perundang-undangan yang berlaku dengan kata lain, adanya kesesuaian antara prosedur dengan substansi sehingga keadilan tersebut dapat diterima oleh masyarakat. ${ }^{7}$

Kepastian hukum merupakan salah satu aspek dalam kehidupan hukum. Arti daripada kepastian itu sendiri adalah hukum berkehendak untuk menciptakan kepastian dalam hubungan antar orang dalam

7 Soerjono Soekanto, Faktor-Faktor yang Mempengaruhi Penegakan Hukum, Jakarta: Rajawali Pers, 2019. hal. 57. 
masyarakat. Dalam proses penegakan hukum perlu memperhatikan kenyataan hukum yang berlaku sehingga kepastian hukum dalam hal ini dapat berguna untuk menciptakan ketertiban masyarakat. Kemanfaatan hukum berarti hukum yang diciptakan diharapkan dapat memberikan manfaat kepada orang banyak.

Fungsi Bhabinkamtibmas telah diatur dalam Keputusan Kapolri Nomor: KEP/773NII/2016. Bhabinkamtibmas memiliki fungsi untuk :

a. membimbing dan menyuluh dibidang hukum dan kamtibmas;

b. melayani masyarakat tentang hal-hal yang berkaitan dengan permasalahan kamtibmas;

c. membina ketertiban masyarakat terhadap norma-norma yang berlaku;

d. memediasi dan memfasilitasi upaya pemecahan masalah yang terjadi di masyarakat;

e. mendinamisir aktivitas masyarakat yang bersifat positif;

f. mengkoordinasikan upaya pembinaan kamtibmas dengan perangkat desa/kelurahan, Babinsa dan pihak-pihak terkait lainnya. Berdasarkan Pasal 26 Perkap Nomor 3 Tahun 2015, Bhayangkara Pembina Keamanan dan Ketertiban Masyarakat (Bhabinkamtbmas) merupakan pengemban Polmas di desa/kelurahan yang memiliki fungsi dalam:

a. melaksanakan sambang kepada masyarakat dengan mendengarkan keluhan dan permasalahan kamtibmas;

b. membimbing masyarakat dibidang hukum dan kamtibmas untuk meningkatkan kesadaran hukum dan kamtibmas;

c. menyebarluaskan informasi yang berkaitan dengan pemeliharaan keamanan dan ketertiban masyarakat;

d. memberikan pelayanan kepolosian kepada masyarakat yang memerlukan;

e. menggerakan kegiatan masyarakat yang bersifat positif;

f. melaksanakan konsultasi;

g. fasilitasi kepada masyarakat dalam hal pemeliharaan keamanan dan ketertiban masyarakat.

Jika dilihat dari aturan hukum yang mengatur fungsi Bhabinkamtibmas terdapat aturan yang berbeda antara Perkap Nomor 3 Tahun 2015 tentang Polmas dengan Keputusan Kaporli Nomor: KEP/773NII/2016. Hal ini menjadikan aturan fungsi Bhabinkamtibmas menjadi lebih banyak dan fungsi Bhabinkamtibmas tidak terfokus pada suatu fungsi. Selain memberikan bimbingan atau membina masyarakat terkait kamtibmas, Bhabinkamtibmas harus menggerakan kegiatan positif di masyarakat, memediasi dan memfasilitasi upaya pemecahan masalah serta memberikan pelayanan kepada masyarakat.

Bhabinkamtibmas juga melaksanakan fungsi Polri dalam bentuk lain diluar daripada 2 peraturan diatas. Bhabinkamtibmas turut menerima pengaduan permasalahan dari masyarakat dan melakukan 
patroli dilingkungan sekitar masyarakat. Dengan kegiatan yang begitu banyak diemban Bhabinakmtibmas dan keadaan fungsi Bhabinkamtibmas yang tidak terfokus, maka pelaksanaan fungsi Bhabinkamtibmas menjadi tidak efektif.

2) Faktor penegak hukum.

Penegak hukum disini berkaitan dengan pihak yang membentuk atau menerapkan suatu hukum. Dalam arti luas, aparatur penegak hukum disini berkaitan dengan institusi penegak hukum dan aparat penegak hukum. Sedangkan dalam artian sempit, penegak hukum berarti aparatur kepolisian, kehakiman, kejaksaan, penasehat hukum dan petugas sipil lembaga pemasyarakatan. Setiap aparatur penegak hukum memilik tugas pokok, fungsi dan kewenangan masing-masing.

Jika dilihat dari segi kuantitas, dapat dikatakan pelaksanaan fungsi Bhabinkamtibmas masih belum efektif. Jumlah personel Bhabinakmtibmas saat ini masih sangat terbatas tidak sesuai dengan sebagaimana mestinya. Harapannya adalah 1 (satu) personel Bhabinkamtibmas untuk 1 (satu) kelurahan/desa namun pada Bhabinkamtibmas Kepolisian Daerah Kepulauan Riau, seorang personel Bhabinkamtibmas harus merangkap untuk menjalankan fungsinya di beberapa wilayah binaan. Hal ini menyebabkan Bhabinkamtibmas dibeberapa Polres di Kepulauan Riau harus merangkap kerja untuk beberapa wilayah binaan.

Dengan kurangnya personel Bhabinkamtibmas, maka sangat berpengaruh terhadap kualitas pelaksanaan fungsi Bhabinkamtibmas Kepolisian Daerah Kepulauan Riau. Pelaksanaan fungsi menjadi tidak efektif, tidak maksimal dan tidak terfokus pada 1 (satu) wilayah binaan. Sehingga, dapat Penulis katakan bahwa pelaksanaan fungsi Bhabinkamtibmas dari faktor penegak hukum masih belum efektif.

3) Faktor sarana atau fasilitas yang mendukung penegakan hukum

Fasilitas pendukung secara sederhana dapat dikatakan sebagai dasar yang dapat digunakan sebagai sarana untuk mencapai tujuan hukum. Fasilitas pendukung mencakup tenaga SDM (sumber daya manusia) yang berpendidikan dan terampil, peralatan yang memadai, keuangan yang mencukupi, organisasi yang baik dan sebagainya.

Setiap personel Bhabinkamtibmas telah dibekali dengan sarana, prasarana dan fasilitas seperti pakaian lengkap personel Bhabinkamtibmas, kendaraan bermotor, handphone, speedboat untuk lintas laut. Berbagai inovasi terus dikembangkan sesuai dengan perkembangan era saat ini seperti fasilitas aplikasi Go Binmas yang diluncurkan untuk merekap kegiatan-kegiatan harian Bhabinkamtibmas oleh masing-masing personel Bhabinkamtibmas di setiap Polres. Kepolisian Daerah Kepulauan Riau juga meluncurkan aplikasi Lapor 
yang disediakan bagi masyarakat yang ingin melaporkan permasalahan kamtibmas.

Bhabinkamtibmas Kepolisian Daerah Kepulauan Riau dibekali dengan banyak kendaraan bermotor roda 2 yang mana menurut Penulis kurang sesuai dengan keadaan geografis Kepulauan Riau yang mayoritas berbatasan langsung dengan perairan laut lepas sehingga untuk bertugas dari 1 wilayah ke wilayah lainnya, sarana dan fasilitas yang cocok adalah kendaraan perairan seperti speedboat. Saat ini Bhabinkamtibmas Kepolisian Daerah Kepulauan Riau sudah mendapatkan fasilitas speedboat air, namun speedboat yang tersedia saat ini masih belum bisa mengakomodir seluruh kegiatan Bhabinkamtibmas sepenuhnya. Jumlah speedboat yang tersedia masih terbatas dan fungsi speedboat yang tersedia tidak sesuai dengan keadaan Kepulauan Riau. Speedboat yang tersedia adalah jenis speedboat untuk perairan dangkal seperti didanau sehingga tidak cocok dengan keadaan perairan laut lepas di wilayah Kepulauan Riau.

Fasilitas lain yang belum memadai adalah upah atau tunjangan kerja atau anggaran bagi personel Bhabinkamtibmas dalam melaksanakan fungsinya yang masih sangat terbatas. Sebagian besar personel Bhabinkamtibmas mengeluarkan gaji pribadi dalam melaksanakan inovasi untuk membantu masyarakat sehingga inovasi dan kegiatan yang dapat dilakukan menjadi terbatas dan tidak maksimal.

Dengan beberapa contoh diatas, Penulis menilai pelaksanaan fungsi Bhabinkamtibmas jika dilihat dari faktor sarana dan fasilitas masih belum efektif. Untuk menunjang efektivitas pelaksanaan fungsi Bhabinkamtibmas maka diperlukannya penambahan dan pembaruan pemberian fasilitas sesuai dengan kebutuhan per wilayah dan kegiatannya.

4) Faktor masyarakat

Efektivitas suatu hukum juga bergantung pada masyarakat. Penegakkan hukum memiliki tujuan untuk mencapai ketentraman dan keamanan di dalam masyarakat. Rendahnya kesadaran masyarakat akan hukum membuat hukum sulit ditegakkan. Dengan menegakkan kebiasaan masyarakat untuk taat hukum serta melakukan sosialisasi berkala dengan mengikutsertakan seluruh lapisan masyarakat akan membuat hukum dapat diterapkan dengan efektif sebagai sarana pengatur perilaku masyarakat sehingga dapat tercipta kondisi lingkungan dan masyarakat yang aman, kondusif dan tentram.

Demi mencapai tujuan masyarakat yang tentram dan aman kegiatan-kegiatan berbasis ketaatan dan kesadaran hukum dilaksanakan dengan memberikan penyuluhan, himbauan maupun kegiatan pembinaan kepada masyarakat baik secara door to door maupun dalam kegiatan desa oleh Bhabinkamtibmas. 
Berdasarkan data penelitian laporan kegiatan Bhabinkamtibmas, masyarakat menyambut kehadiran dan setiap kegiatan Bhabinkamtibmas dengan antusiasme yang tinggi. Hal ini tergambar dari keikutsertaan masyarakat dalam setiap kegiatan Bhabinkamtibmas. Masyarakat juga bersedia untuk mengikuti arahan-arahan Bhabinkamtibmas dalam menjaga keamanan dan ketertiban lingkungan. Sehingga Penulis menilai pelaksanaan fungsi Bhabinkamtibmas jika dilihat dari faktor masyarakatnya sudah efektif.

5) Faktor kebudayaan

Faktor kebudayaan memiliki hubungan yang sangat erat dengan masyarakat. Hukum dapat mendorong dan memberikan dampak perubahan sosial terhadap kebudayaan yang tumbuh dan berkembang dalam masyarakat.

Menurut Soerjono Soekanto, suatu sikap tindak perilaku hukum dianggap efektif apabila sikap, tindakan atau perilaku menuju pada tujuan yang dikehendaki. Undang-Undang dapat menjadi efektif apabila peranan yang dilakukan penegak hukum dan masyarakat semakin mendekati apa yang diharapkan oleh undang-undang dan sebaliknya menjadi tidak efektif jika peranan yang dilakukan oleh penegak hukum jauh dari apa yang diharapkan undang-undang.

Fungsi Bhabinkamtibmas adalah membina ketertiban masyarakat terhadap norma-norma yang berlaku dan meningkatkan aktifitas masyarakat yang bersifat positif. Kedua fungsi tersebut berkaitan dengan faktor kebudayaan dalam teori efektivitas hukum Soerjono Soekanto karena dengan dilaksanakannya kegiatan-kegiatan positif dan pembinaan norma-norma masyarakat dapat membentuk karakteristik perilaku masyarakat agar dapat menuju tujuan hukum dan sesuai dengan undang-undang.

Berdasarkan data penelitian laporan kegiatan Bhabinkamtibmas Kepolisian Daerah Kepulauan Riau, Bhabinkamtibmas Kepolisian Daerah Kepulauan Riau melaksanakan aktivitas positif secara berkala dan berkelanjutan. Adapun kegiatan yang dilaksanakan seperti kegiatan pembinaan, himbauan, penyuluhan, penanganan permasalahan kamtibmas, gotong royong, bakti sosial, kegiatan keagamaan dan kegiatan-kegiatan lainnya. Bhabinkamtibmas mampu menumbuhkan kebudayaan melakukan kegiatan-kegiatan positif di masyarakat.

Pelaksanaan kegiatan Bhabinkamtibmas tidak hanya berfokus pada salah satu etnis/agama/atau budaya, melainkan secara menyeluruh kepada setiap masyarakat tanpa memandang suatu etnis/agama/atau budaya. Sehingga Penulis menilai, pelaksanaan fungsi Bhabinkamtibmas dilihat dari faktor kebudayaan sudah efektif. 


\section{E. Kesimpulan}

Kesimpulan atas penelitian terkait Efektivitas Pelaksanaan Fungsi Bhabinkamtibmas Dalam Wilayah Hukum Kepolisian Daerah Kepulauan Riau:

1. Bhabinkamtibmas Kepolisian Daerah Kepulauan Riau telah melaksanakan fungsi Bhabinkamtibmas sesuai dengan Peraturan Kapolri Nomor 3 Tahun 2015 Tentang Polmas dan Keputusan Kapolri Nomor : KEP/773NII/2016. Pelaksanaan fungsi-fungsi Bhabinkamtibmas dilaksanakan dengan kegiatan-kegiatan bersama masyarakat seperti kegiatan himbauan, pembinaan, pengamanan keamanan lingkungan (siskamling), sambang, pemecahan masalah, gotong royong, pendampingan dana desa, musrembang, bakti sosial, pelatihan kemampuan dasar Bhabinkamtibmas, dan sebagainya. Kegiatan-kegiatan positif ini sejalan dengan fungsi Bhabinkamtibmas dan perannya sebagai ujung tombak Polri dalam membangun sinergitas dengan masyarakat, membangun kesadaran masyarakat akan norma-norma dan hukum yang berlaku serta sebagai upaya preventif tindak kejahatan dan memelihara lingkungan agar tetap dalam keadaan yang aman, tentram dan kondusif.

2. Pelaksanaan fungsi Bhabinkamtibmas Kepolisian Daerah Kepulauan Riau masih belum efektif. Terlihat dari hasil perbandingan terjadinya tindak pidana pada tahun 2019 mengalami peningkatan sebanyak 55 kasus dibandingkan tahun 2018.

Faktor-faktor yang masih belum efektif, sebagai berikut:

a. Faktor hukumnya sendiri, saat ini fungsi Bhabinkamtibas diatur didalam beberapa literatur peraturan perundang-undangan di Indonesia yang berbeda dan fungsi Bhabinakmtibmas diatur dalam jumlah yang cukup banyak. Bhabinkamtibmas juga melaksanakan fungsi diluar daripada yang telah diatur pada Perkap Polri Nomor 3 Tahun 2015 dan Surat Keputusan Polri Nomor KEP/773NII/2016. Sehingga Bhabinkamtibmas tidak dapat berfokus pada suatu fungsi tertentu dan berdampak pada kurang maksimalnya pelaksanaan fungsi Bhabinkamtibmas.

b. Faktor penegak hukum, secara kuantitas jumlah personel Bhabinkamtibmas Kepolisian Daerah Kepulauan Riau masih sangat terbatas sehingga mengharuskan seorang personel Bhabinkamtibmas melaksanakan fungsinya untuk beberapa wilayah binaan sekaligus. Dengan jumlah personel Bhabinkamtibmas yang terbatas namun banyak fungsi yang harus dilaksanakan maka akan sangat mempengaruhi kualitas pelaksanaan fungsi Bhabinkamtibmas menjadi tidak maksimal.

c. Faktor sarana dan fasilitas, jumlah sarana dan fasilitas yang tersedia masih terbatas dan belum sesuai dengan kebutuhan diwilayah Kepulauan Riau yang terbagi menjadi beberapa wilayah kepulauan dan berbatasan langsung dengan perairan laut lepas. Selain itu, masih minimnya upah atau anggaran untuk melaksanakan inovasi-inovasi personel Bhabinkamtibmas dan kegiatan di masyarakat.

Sedangkan faktor-faktor yang sudah efektif sebagai berikut: 
a. Faktor masyarakat, kehadiran dan kegiatan Bhabinkamtibmas sangat disambut antusias oleh masyarakat. Mayoritas masyarakat bersedia untuk ikut serta pada setiap kegiatan yang diadakan Bhabinkamtibmas dan mengikuti arahan/bimbingan dari Bhabinkamtibmas untuk turut menjaga keadaan lingkungan yang aman dan tentram.

b. Faktor budaya, Bhabinkamtibmas melaksanakan kegiatan-kegiatan positif secara rutin dan berkala. Bhabinkamtibmas menumbuhkan kebiasaan kegiatan positif tersebut untuk hidup dimasyarakat sehingga dapat tercapai masyarakat yang kondusif dan situasi lingkungan yang aman dan tentram. 


\section{DAFTAR PUSTAKA}

\section{BUKU}

Poernomo, Bambang, Asas-Asas Hukum Pidana, Jakarta: Ghalia Indonesia, 1992.

Soekanto, Soerjono, Faktor-Faktor yang Mempengaruhi Penegakan Hukum, Jakarta: Rajawali Pers, 2019.

\section{JURNAL}

Kristiani, Ni Made, "Kejahatan Kekerasa Seksual (Perkosaan) Ditinjau dari Perspektif Kriminologi, Jurnal Magister Hukum Udayana, Vol.7, No. 3, Tahun 2014.

\section{INTERNET}

Admin, "Ini 3 Agenda Paket Reformasi Jilid II" https://www.hukumonline.com/berita/baca/lt587e0fdb06ea8/ini-3-agendapaket-reformasi-hukum-jilid-ii/. Diunggah pada 17 Januari 2017.

Hernowo Yuliantor, "Laporan Analisa dan Evaluasi Data Kriminalitas Tindak Pidana Umum Pada Ditreskrimum dan Satreskrimum Jajaran Polda Kepri Bulan Oktober 2018”. $\quad$ http://kepri.polri.go.id/pid/wpcontent/uploads/2018/11/LAPBUL-ANEV-DATA-KRIMINALITASBULAN-OKT-2018.pdf, diunggah pada 19 November 2018.

\section{PERATURAN PERUNDANG-UNDANGAN}

Indonesia. Undang-Undang Dasar Negara Republik Indonesia Tahun 1945.

Indonesia. Undang-Undang Kepolisian Negara Republik Indonesia. UU Nomor 2 Tahun 2002.

Indonesia. Pemolisian Masyarakat. Peraturan Kapolri Nomor 3 Tahun 2015.

Indonesia. Kebiajakan dan Strategi Penerapan Model Perpolisian Masyarakat. Keputusan Kapolri No. Pol. SKep/737/X/2005.

Indonesia. Buku Pintar Bhabinkamtibmas. Keputusan Kapolri Nomor Skep/773NII/2016. 